\title{
Neptunian dykes in the Middle Miocene reefs of western Ukraine: preliminary results
}

\author{
Marek JASIONOWSKI, Danuta PERYT and Tadeusz Marek PERYT
}

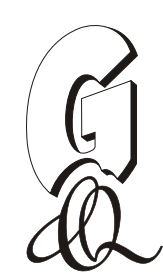

Jasionowski M., Peryt D. and Peryt T.M. (2012) - Neptunian dykes in the Middle Miocene reefs of western Ukraine: preliminary results. Geol. Quart., 56 (4): 881-894, doi: 10.7306/gq.1066

\begin{abstract}
Neptunian dykes were recently recorded within the Middle Miocene (Upper Badenian and Lower Sarmatian) Medobory reef complex of the Carpathian Foreland in western Ukraine. The Upper Badenian reefs are cut by a regular, semi-perpendicular network of intersecting fissures that penetrate the Badenian reef limestone down for more than $10 \mathrm{~m}$. The dykes are filled by several generations of Sarmatian microbialites coating the fracture walls and by bedded bioclastic sediment (including foraminifers) which is more important volumetrically. The fissure fillings containing both the Sarmatian material as well as rare clasts of Badenian rocks indicate that the fissures were open during the onset of Sarmatian deposition. They originated following the emergence and fracturing of the Badenian limestones, either due to fault tectonics at basin margins induced by basin subsidence, around the Badenian-Sarmatian boundary, or to gravitational instability of large lithified Badenian reef bodies. Only one phase of fracture opening occurred. The filling of fractures was episodic, with pulses of cementation and microbial growth and sediment injection. Four different foraminiferal assemblages recorded in the neptunian dykes indicate that the process of fracture filling was long-lasting.
\end{abstract}

Marek Jasionowski and Tadeusz Marek Peryt, Polish Geological Institute - National Research Institute, Rakowiecka 4, 00-975 Warszawa, Poland, e-mails: marek.jasionowski@pgi.gov.pl, tadeusz.peryt@pgi.gov.pl; Danuta Peryt, Institute of Paleobiology, Polish Academy of Sciences, Twarda 51/55, 00-818 Warszawa, Poland, e-mail:d.peryt@twarda.pan.pl (received: October 26, 2012; accepted: December 3, 2012; first published online: December 14, 2012).

Key words: Sarmatian, foraminifers, reefs, sedimentology, palaeoenvironments, Ukraine.

\section{INTRODUCTION}

Neptunian dykes are bodies of younger sediment infilling fissures in rocks exposed on the sea-floor and are the marine equivalents of terrestrial (often karstic) fissure fills with which they may be genetically related. They are particularly associated with carbonate buildups due to three factors: (1) as carbonates become lithified much more rapidly than siliciclastic rocks, they respond in a brittle manner to stress and develop fractures even at an early stage; (2) carbonate slopes tend to steepen upwards and develop fractures due to unloading and mass movement along the platform margins; (3) substantial voids can be formed due to circulation of undersaturated waters (Smart et al., 1988).

Neptunian dykes were recently recorded within the Middle Miocene (Upper Badenian and Lower Sarmatian) reef complex that extends for more than $200 \mathrm{~km}$ in western Ukraine in the Carpathian foreland located north of the Carpathian Foredeep Basin, a sub-basin of the Central Paratethys (Fig. 1) that is filled by mostly Middle Miocene strata of thickness reaching $5.5 \mathrm{~km}$. The reef complex forms the Medobory Hills (Fig. 2). Their most prominent component are Upper Badenian coralline algal reefs that are associated with a variety of bioclastic, marly and rhodoid facies. The coralline algal reefs are covered by Lower Sarmatian serpulid-microbialite reefs. The Sarmatian reefs occur also within marly and clayey deposits at the SW foot of the Medobory Ridge where they build rocky hills a few ten of metres high. The Middle Miocene reefs of Medobory have been studied for more than one century (see Korolyuk, 1952; Maslov, 1962) but the occurrence of neptunian dykes has been mentioned only recently (Radwański et al., 2006b). The neptunian dykes are a potentially important source of information revealing the history of the reefs and in this paper we focus on three localities: Maksymivka, Polupanivka and Hai Roztotski, where the Upper Badenian reefs are cut by a regular, semi-perpendicular network of intersecting fissures that penetrate Badenian reef limestone; the fissures are more than $10 \mathrm{~m}$ deep (e.g., Fig. 3). 


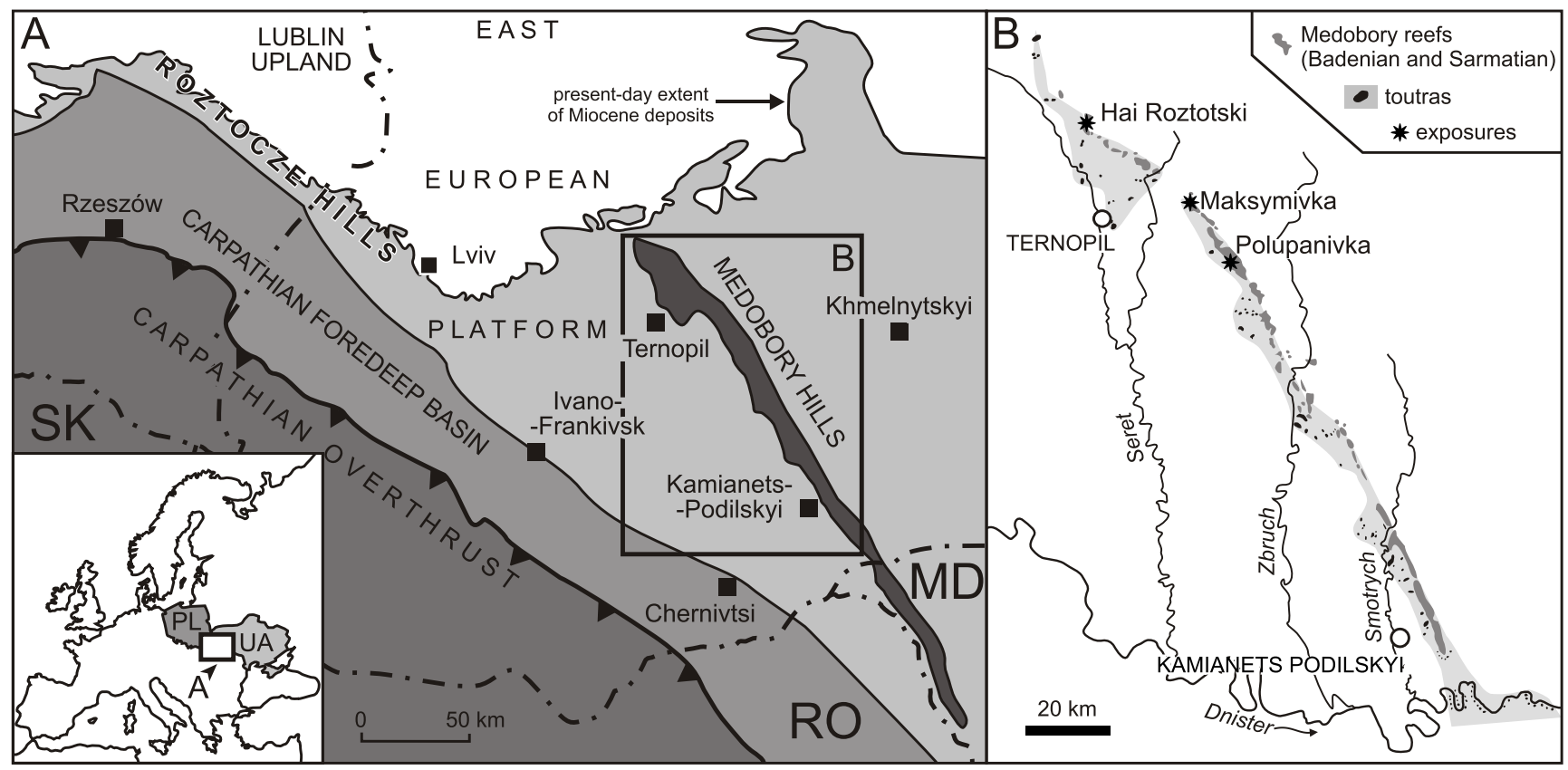

Fig. 1A - map of the Middle Miocene deposits in the Carpathian Foredeep Basin in Poland and Ukraine, showing the distribution of reef deposits (solid shading); B - distribution of the Badenian and Sarmatian reefs of the Medobory Hills with location of the outcrops studied (after Korolyuk, 1952; modified)

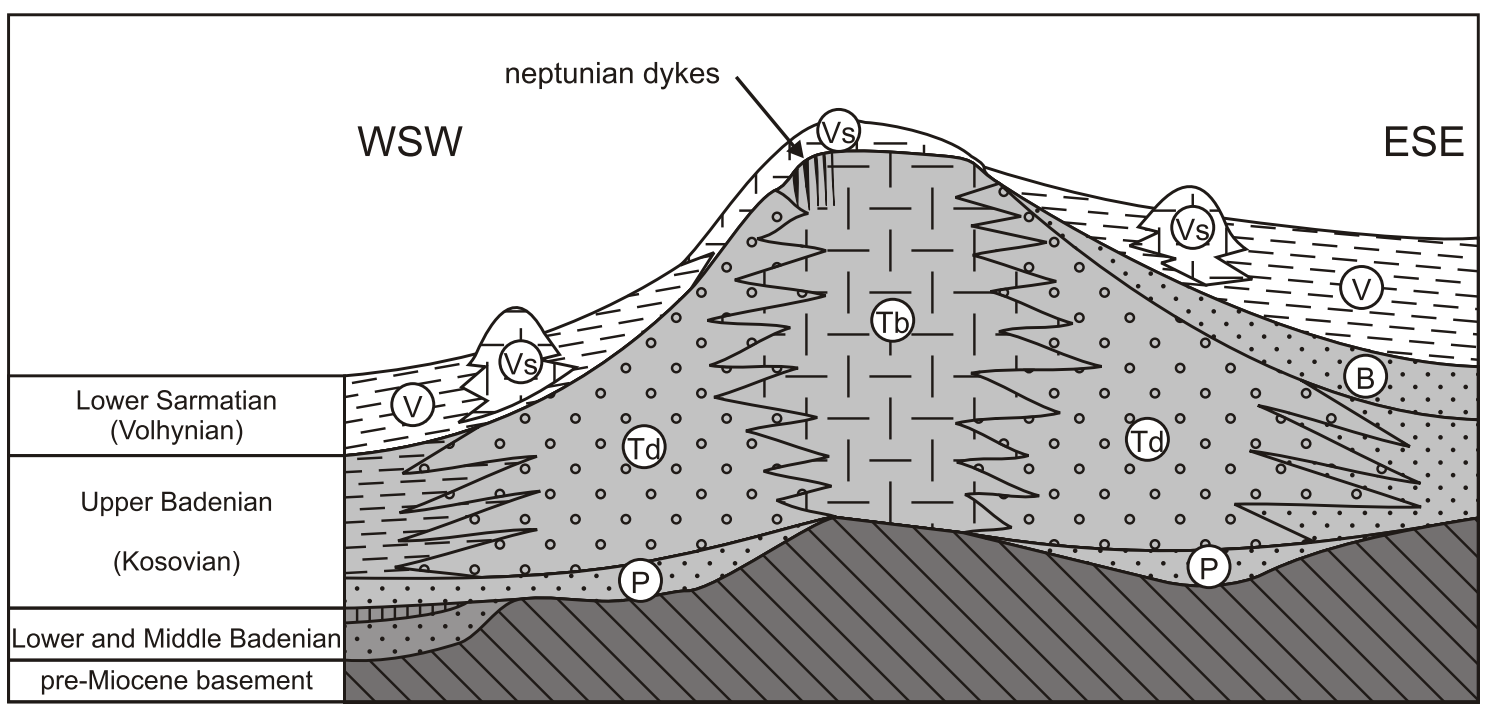

Fig. 2. Schematic geological cross-section through Medobory (after Górka et al., 2012, modified)

B - Vyshhorodok Beds and Buhliv Beds (sands), P - Pidhirtsi Beds (sands), Tb - Ternopil Beds (reef facies), Td - Ternopil Beds (organodetrital facies), V - Volhyn Beds including Sarmatian serpulid-microbialite reefs (Vs)

\section{GEOLOGICAL SETTING}

The Middle Miocene strata of the Carpathian foreland in western Ukraine rest upon Upper Cretaceous and MiddleLower Paleozoic deposits of the East European Platform. During the Paleogene the area of Carpathian foreland was subject to erosion until the Early Badenian regional transgression (Oszczypko et al., 2006); only locally were Eocene deposits encountered. The northern marginal area of the Early Badenian sea was occupied by littoral sands (Mykolaiv Beds) and coralline algal deposits (Naraiv Beds; Andreyeva-Grigorovich et al.,
1997; Wysocka et al., 2012). On the relatively wide $(50-100 \mathrm{~km})$ northern shelf (outer foredeep) siliciclastic sediments of the Zhuriv and Baranów beds were deposited. The area of Medobory was flooded only in the Late Badenian owing to relative sea level rise; the rise was perhaps linked with tectonic subsidence related to a Late Badenian increased rate of overthrusting within the Carpathian accretionary wedge and/or increased slab-pull processes within the Carpathian subduction zone (Oszczypko et al., 2006).

Upper Badenian and Lower Sarmatian reefs occur in a zone a few $\mathrm{km}$ to $40 \mathrm{~km}$ wide and more than $200 \mathrm{~km}$ long (Fig. 1). 

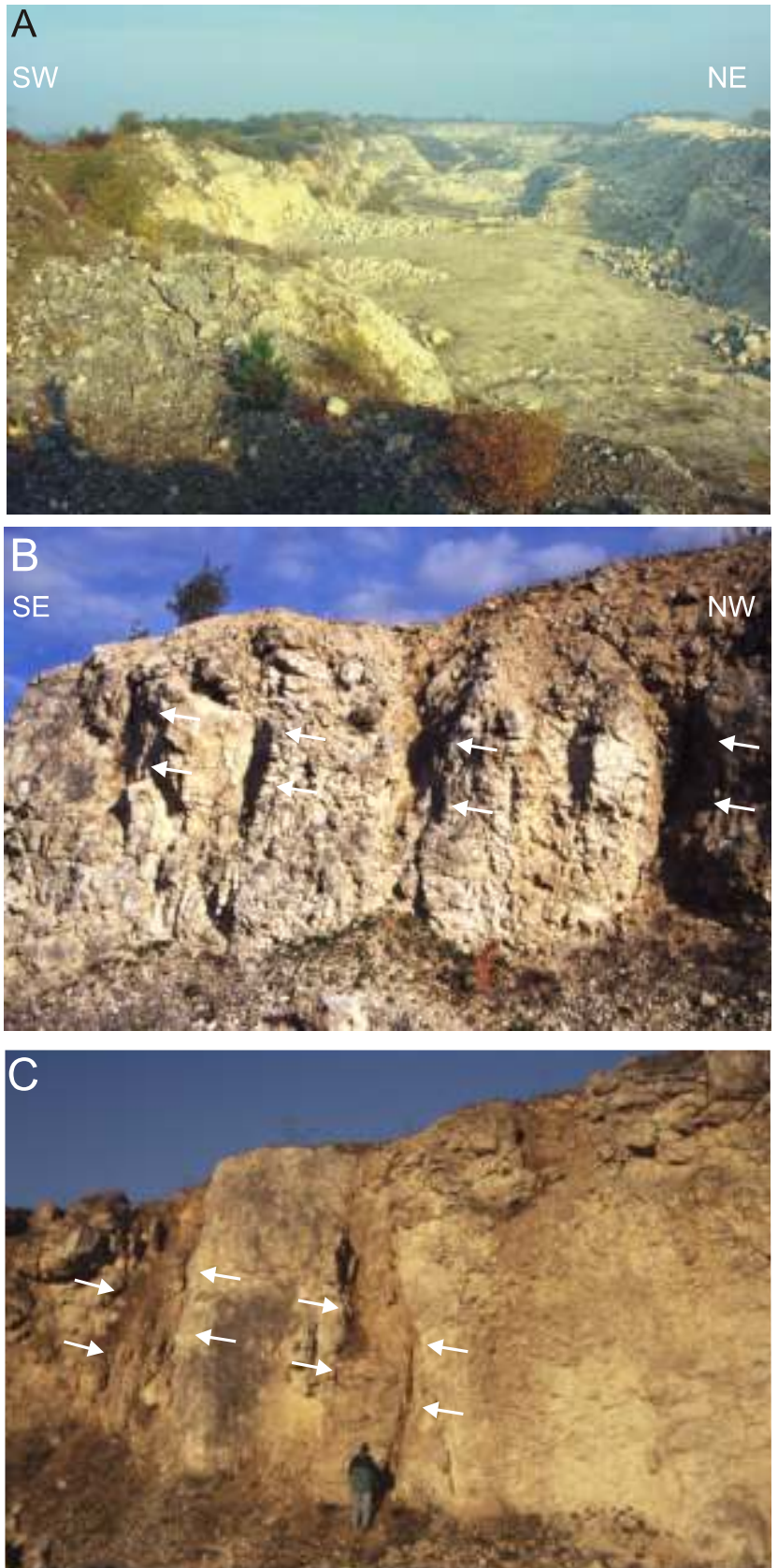

Fig. 3A - general view of the Maksymivka Quarry; fissures occur in the south-west wall of the quarry (left). The pit is cut into the Badenian reef. Sarmatian rocks occur in the uppermost parts of the quarry walls; B - wall of the the Maksymivka Quarry with semi-vertical joints or very narrow fissures that cut the Badenian reef limestone; $\mathbf{C}$ - southwestern face of the Maksymivka Quarry built by the Badenian reef limestone cut by wide vertical fissures that are filled with Sarmatian deposits; arrows point to the fissures

The reef zone consists predominantly of Upper Badenian coralline algal boundstones up to $100 \mathrm{~m}$ thick in its axial part and bioclastic grainstones and rudstones on the reef slopes (Korolyuk, 1952; Janakevich, 1977; Radwański et al., 2006a; Górka et al., 2012). The main frame-builders in the Upper Badenian reefs are crustose coralline algae with scattered hermatypic corals. Particular coralgal buildups of variable size are composed of red-algal colonies interfingering with, and/or encrusted by, biolithic mats/crusts of supposedly blue-green algal origin (Radwański et al., 2006a). The coralline algae dis- play different growth morphologies ranging from laminar crusts to erect branching forms. Reef-associated biota comprises rich assemblages of bivalves and gastropods, echinoids, crustaceans, foraminifers, bryozoans and serpulids. In places, boring organisms are of great importance. The coralgal buildups are separated by calcarenites and/or calcirudites. The Medobory reefs separated deeper environments of the Carpathian foreland where mostly marls with intercalations of rhodoid limestone were deposited; towards the Carpathian Foredeep Basin these pass into claystones and marls (Gedl and Peryt, 2011), with nearshore facies dominated by white quartzose sands and sandstones, discordantly overlying the pre-Neogene basement (Maslov and Utrobin, 1958). Field observations have shown the presence of breccias, vadose silt and vadose leaching in the uppermost coralline-algae boundstones, indicating considerable sea level fluctuations and a phase of emergence of the Medobory reefs in the latest Badenian (Jasionowski, 2006).

The Lower Sarmatian serpulid-microbialite reefs cover the western slopes of the Upper Badenian reefs and seldom overlie their tops; they also occur at the south-west foot of those reefs forming isolated mounds (called toutra) up to a few tens of metres high (Jasionowski, 2006; Górka et al., 2012). The reefs are composed of calcitic precipitates of microbial and inorganic origin with numerous serpulid tubes. The major reef component comprises microbialites. The reef biota is taxonomically very poor and represented by a few species of bivalves, gastropods, bryozoans, foraminifers and ostracods typical of a semimarine environment. The microbialites and the serpulid or bryozoan skeletons together form a cavernous framework that is usually filled up with abundant synsedimentary fibrous cements and micritic internal sediments (Jasionowski, 2006; Studencka and Jasionowski, 2011).

The top surface of the Upper Badenian reef in its axial part is cut horizontally and leveled, suggesting that it represents a submarine abrasion surface. The overlying Sarmatian deposits are several metres thick and show very high facies differentiation. The southwestern slopes of the Upper Badenian reefs dip steeply towards the south and show very varied relief (Radwański et al., 2006b). The contact of Upper Badenian and Sarmatian deposits, often vertical, is encrusted by red algae and nubecularian foraminifera.

\section{MATERIAL AND METHODS}

The Maksymivka Quarry $\left(49.592^{\circ} \mathrm{N}, 25.868^{\circ} \mathrm{E}\right)$ is located $20 \mathrm{~km}$ east of the city of Ternopil in the central section of the Medobory Hills (Fig. 1). This huge quarry, embracing an area of several square kilometres, is some tens of metres deep and exploits mainly Upper Badenian reef limestones (Fig. 3A). In Maksymivka the largest fissures occur in the external parts of the reefs (Fig. 3B, C); toward the reef centre they are narrower and eventually disappear. The fissure widths range from a few centimetres up to more than $1 \mathrm{~m}$ (Figs. 3-5 and 6A). A similar situation is observed in other quarries such as Polupanivka $\left(49.486^{\circ} \mathrm{N}, 25.960^{\circ} \mathrm{E}\right)$ or Hai Roztotski $\left(49.831^{\circ} \mathrm{N}, 25.440^{\circ} \mathrm{E}\right)$.

The microfacies and petrography of the fissure fills were studied in standard thin section. For stable isotope analysis, the slabbed specimens (with the other slab used to produce stan- 


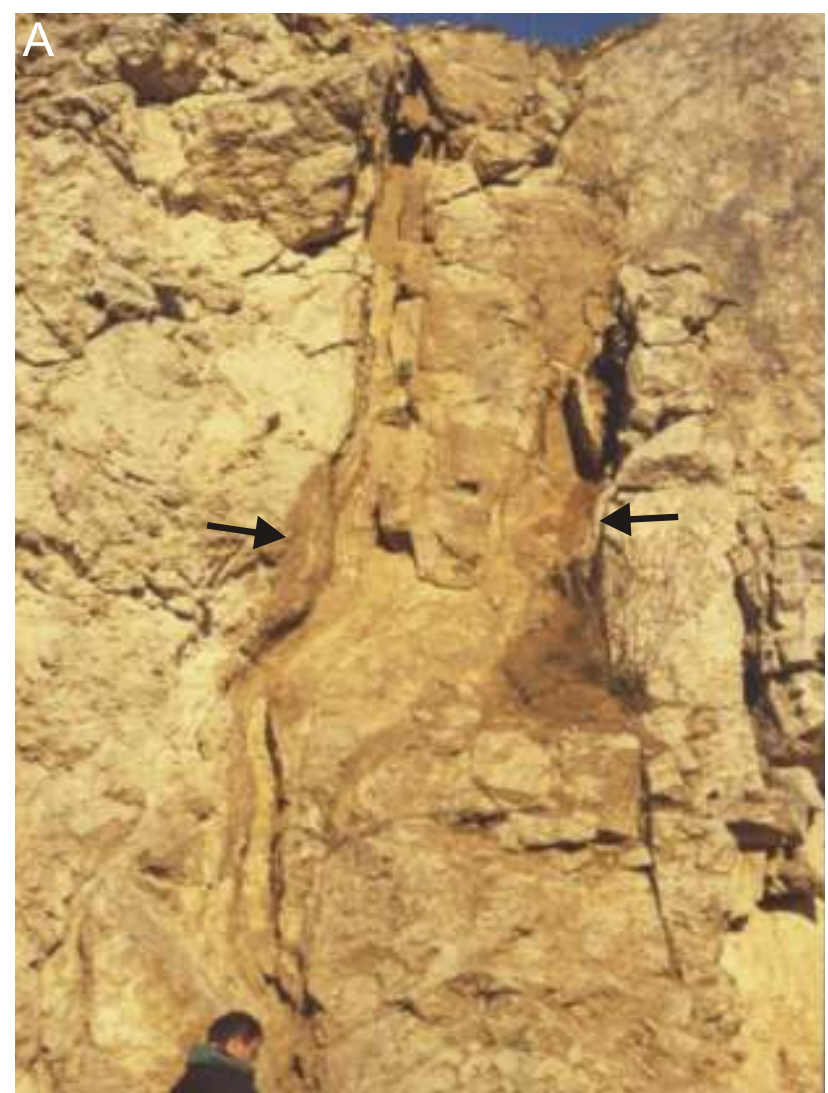

B

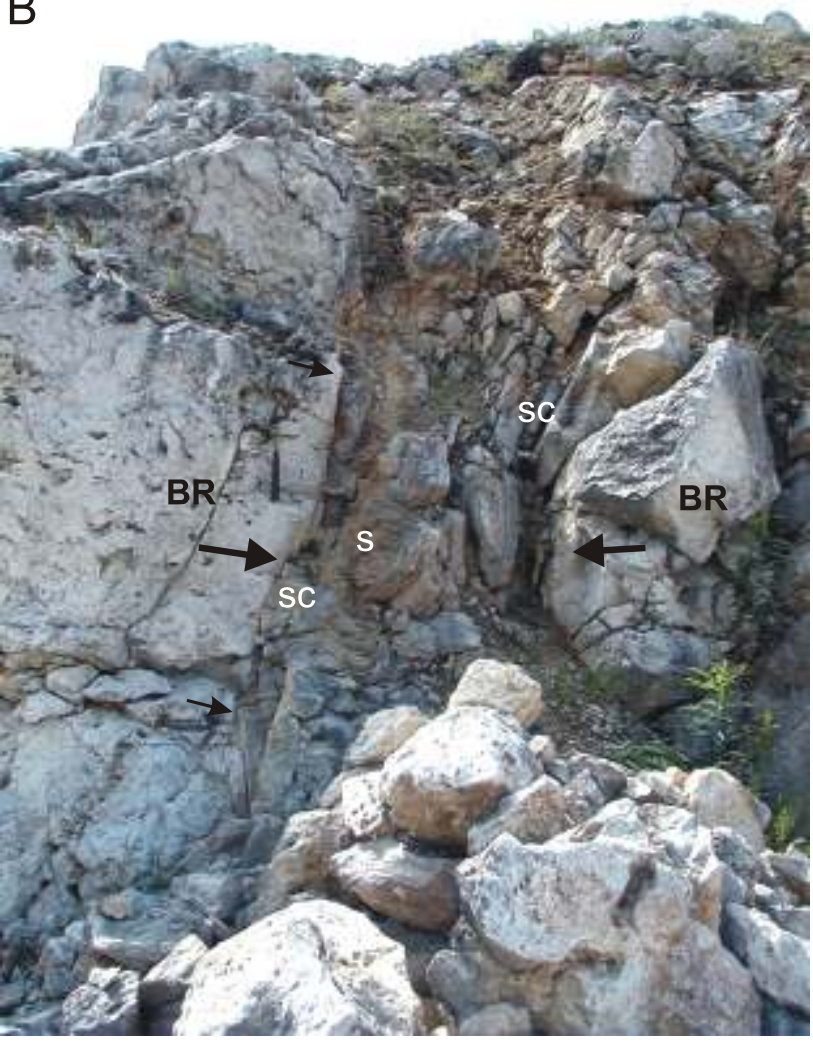

Fig. 4A, B - wide fissures in the Badenian reef limestone (Maksymivka Quarry)

Arrows indicate fissure walls that are coated with Sarmatian microbialite encrustations; BR - Badenian reef rock, sc - microbial encrustation, s Sarmatian bedded shelly deposits filling the fissures
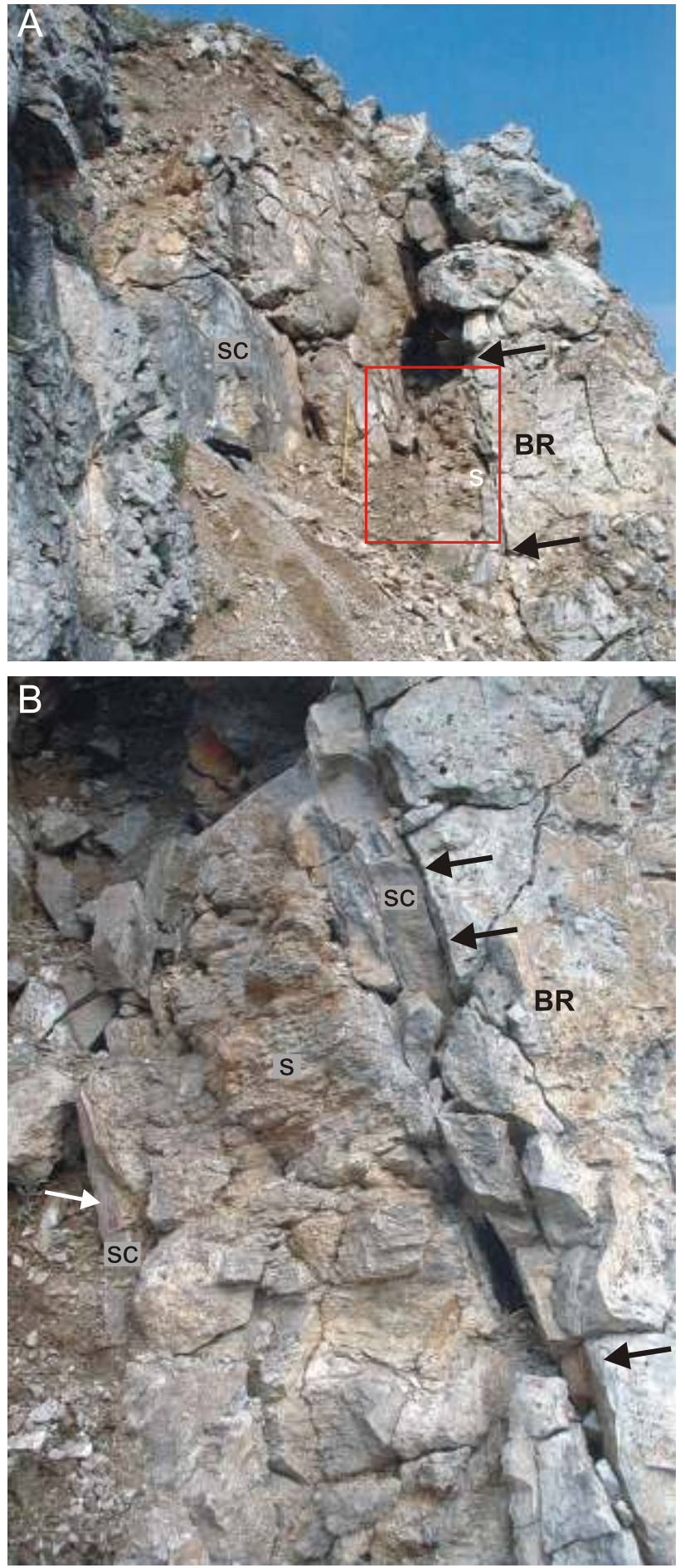

Fig. 5A, B - wide fissures in the Badenian reef limestone (Maksymivka Quarry)

Red quadrangle in A shows the fragment in B; black arrows indicate fissure walls that are coated with Sarmatian microbialite encrustations; white arrow shows sample shown in Figure 6; for other explanations see Figure 4

dard thin sections) were sampled selectively with a $1.5 \mathrm{~mm}$ diameter stainless steel drill with tungsten carbide coating. 23 samples from 5 slabs were analysed (cf. Table 2). Considering the diameter of sampling $(1.5 \mathrm{~mm})$ and the petrographic variability shown by the rocks studied, the isotopic sampling has to be regarded as representing whole rock samples. 
Mineralogy (XRD) and geochemistry (XRF) of fissure microbialites and cements

\begin{tabular}{|c|c|c|c|c|c|c|c|c|c|c|c|c|}
\hline No. & Sample & Description & $\begin{array}{c}\mathrm{M} \text { ineralogy } \\
{[\mathrm{XRD}]}\end{array}$ & $\begin{array}{c}\mathrm{Sr} \\
{[\mathrm{ppm}]}\end{array}$ & $\begin{array}{c}\mathrm{Mg} \\
{[\mathrm{ppm}]}\end{array}$ & $\begin{array}{c}\mathrm{MnO} \\
{[\%]}\end{array}$ & $\begin{array}{c}\mathrm{Fe}_{2} \mathrm{O}_{3} \\
{[\%]}\end{array}$ & $\begin{array}{c}\mathrm{SiO}_{2} \\
{[\%]}\end{array}$ & $\begin{array}{c}\mathrm{Al}_{2} \mathrm{O}_{3} \\
{[\%]}\end{array}$ & $\begin{array}{c}\mathrm{TiO}_{2} \\
{[\%]}\end{array}$ & $\begin{array}{c}\mathrm{P}_{2} \mathrm{O}_{5} \\
{[\%]}\end{array}$ & $\begin{array}{c}\mathrm{SO}_{3} \\
{[\%]}\end{array}$ \\
\hline 1 & $\mathrm{M} 4 / 02-1$ & microbialite & calcite & 463 & 6151 & 0.053 & 1.11 & 1.35 & 0.27 & 0.01 & 0.079 & 0.01 \\
\hline 2 & $\mathrm{M} 4 / 03 \mathrm{TP}-1$ & microbialite & na & 1234 & 10553 & 0.039 & 0.09 & 0.44 & 0.07 & 0.01 & 0.053 & 0.09 \\
\hline 3 & $\mathrm{M} 5 / 03 \mathrm{TP}-1$ & cement & calcite & 1687 & 4101 & 0.012 & 0.03 & 0.50 & 0.05 & 0.01 & 0.018 & 0.08 \\
\hline 4 & $\mathrm{M} 12 / 03-1$ & microbialite & na & 508 & 8020 & 0.080 & 0.11 & 1.61 & 0.14 & 0.01 & 0.100 & 0.03 \\
\hline 5 & $\mathrm{M} 15 / 03-1$ & microbialite & $\begin{array}{c}\mathrm{Mg} \text {-calcite, } \\
\text { calcite }\end{array}$ & 1215 & 10312 & 0.027 & 0.04 & 0.20 & 0.05 & 0.01 & 0.061 & 0.09 \\
\hline 6 & $\mathrm{M} 19 / 03-1$ & microbialite & na & 410 & 6513 & 0.060 & 0.13 & 0.40 & 0.07 & 0.01 & 0.109 & 0.08 \\
\hline 7 & $\mathrm{M} 19 / 03-2$ & microbialite & na & 328 & 5066 & 0.124 & 0.08 & 0.75 & 0.14 & 0.01 & 0.120 & 0.02 \\
\hline 8 & $\mathrm{M} 20 / 03-1$ & microbialite & $\begin{array}{c}\text { Mg-cacite, } \\
\text { calcite }\end{array}$ & 1030 & 8865 & 0.040 & 0.06 & 0.25 & 0.05 & 0.01 & 0.070 & 0.12 \\
\hline 9 & $\mathrm{M} 20 / 03-2$ & microbialite & na & 1305 & 9950 & 0.060 & 0.08 & 0.41 & 0.05 & 0.01 & 0.900 & 0.22 \\
\hline
\end{tabular}

na - not analysed

$\mathrm{CO}_{2}$ was extracted from the samples using the selective chemical separation technique described by Al-Aasm et al, (1990). $\mathrm{CO}_{2}$ was obtained at $25^{\circ} \mathrm{C}$ in 2 hours of reaction with $100 \%$ phosphoric acid for analysis of calcite. Then the sample kept on reacting until the next day and thereafter all $\mathrm{CO}_{2}$ was pumped away. After that, the reaction was continued at $50^{\circ} \mathrm{C}$ over 2 days and $\mathrm{CO}_{2}$ was collected for the isotopic analysis of dolomite. The isotopic analysis was performed on a dual inlet and triple collector mass spectrometer with standard uncertainty of $\delta^{13} \mathrm{C}$ and $\delta^{18} \mathrm{O}$ values of $0.07 \%$. Results of the stable isotope analyses made at the Mass Spectrometry Laboratory of the Maria Curie-Skłodowska University (Lublin) are given relative to the VPBD standard.

Mineralogical (XRD) and elemental geochemical (XRF) analyses (4 and 9 samples respectively) were measured on a sequence fluorescence spectrometer XRF (using a Philips $P W$ 2400 spectrometer at the Central Chemical Laboratory of the Polish Geological Institute).

For micropalaeontological analysis three samples of marly clays and clayey carbonate sand were taken from Hai Roztotski, two samples from the fissure shown in Figure 5 at Maksymivka and three samples of marly clays and clayey carbonate sand from the infills of fissures and karst caverns at Polupanivka (see Peryt and Jasionowski, 2012). Washed residues for foraminiferal study were obtained from the rocks by disaggregation using $\mathrm{Na}_{2} \mathrm{SO}_{4}$. An aliquot of about 250 or more specimens from the 100-700 $\mu \mathrm{m}$ size fraction was used for foraminiferal counts. The palaeoenvironmental interpretation based on foraminifers applies the requirements of present-day representatives of the taxa recorded (Murray, 1991, 2006; Langer, 1993; Hayward et al., 1997; Geslin et al., 2000).

\section{RESULTS}

\section{FACIES}

The fissures locally show a regular pattern suggesting that they are related to joints in meridional, SW-NE, and

\begin{tabular}{|c|c|c|c|}
\hline No. & Sample & $\begin{array}{c}\delta^{18} \mathrm{O} \\
{[\% \circ \mathrm{VPDB}]}\end{array}$ & $\begin{array}{c}\delta^{13} \mathrm{C} \\
{[\% \circ \mathrm{VPDB}]}\end{array}$ \\
\hline 1 & MS20/03-0 & -2.06 & 0.80 \\
\hline 2 & MS20/03-1 & -0.52 & 2.17 \\
\hline 3 & MS20/03-2 & -1.78 & 1.03 \\
\hline 4 & MS20/03-3 & -0.46 & 1.69 \\
\hline 5 & MS20/03-4 & -1.08 & 1.57 \\
\hline 6 & MS20/03-5 & 0.28 & 2.61 \\
\hline 7 & M2-1 & -2.61 & -0.11 \\
\hline 8 & M2-2 & -0.02 & -1.93 \\
\hline 9 & M2-2a & -5.15 & 1.89 \\
\hline 10 & M2-3 & -1.79 & 1.29 \\
\hline 11 & M2-4 & 0.16 & 2.45 \\
\hline 12 & M2-5 & -6.60 & -5.79 \\
\hline 13 & M16/03-1 & -0.28 & 1.97 \\
\hline 14 & M16/03-2 & 0.58 & 2.12 \\
\hline 15 & M16/03-3 & 0.21 & 2.07 \\
\hline 16 & M16/03-4 & -1.60 & 2.04 \\
\hline 17 & M16/03-5 & -0.19 & 2.18 \\
\hline 18 & M12/03-1 & -1.38 & 1.55 \\
\hline 19 & M12/03-2 & -1.14 & 1.85 \\
\hline 20 & M12/03-3 & -0.69 & 1.63 \\
\hline 21 & M19/03-1 & -0.64 & -0.99 \\
\hline 22 & M19/03-2 & -3.50 & 0.79 \\
\hline 23 & M19/03-3 & -5.32 & -1.16 \\
\hline
\end{tabular}



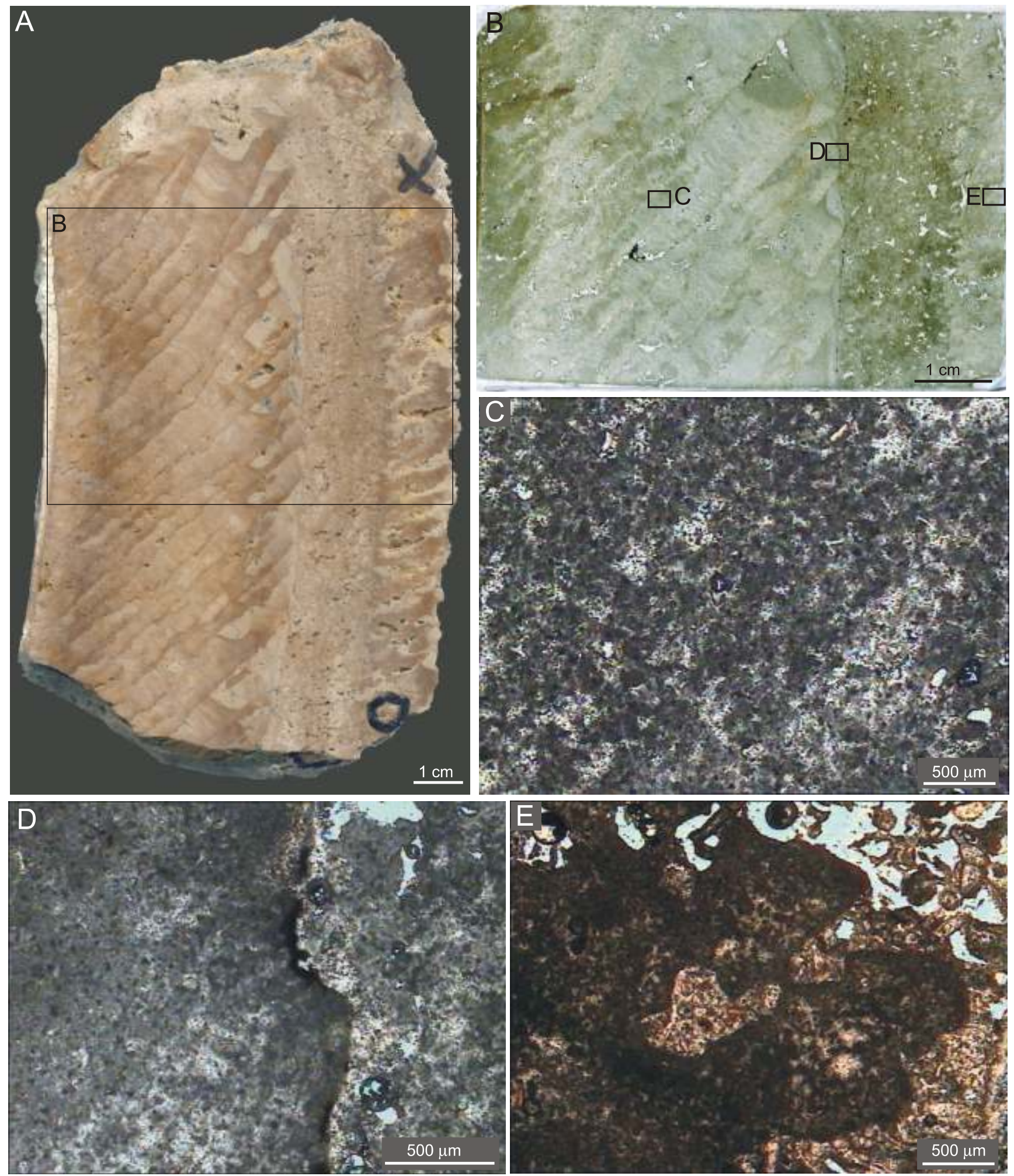

Fig. 6. Three-generation microbialite encrustation at Maksymivka (sample M2-15)

A, B - each generation shows a distinct growth pattern, direction growth was from left to right and upwards: A - polished slab, natural orientation, B - microphotograph of large thin section, equivalent to the slab portion marked with the box at picture A; $\mathbf{C}-\mathbf{E}$ - microphotographs of various microbialite fabrics - clotted and massive microstructures are easily visible, location of the pictures marked at picture B 


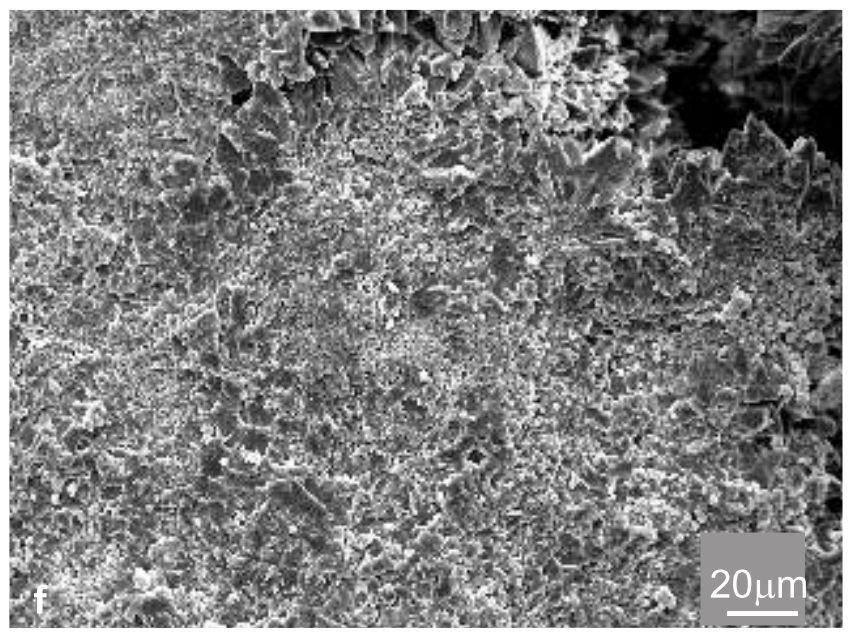

Fig. 7. Peloidal clotted fabrics made up of aggregates of small peloids and sparitic rims (Maksymivka, SEM picture)

WNW-ESE directions characteristic of Neogene deposits of the Podolian part of the East European Platform (Klimchouk et al., 1995). Their surfaces are often encrusted by microbial crusts and in some places also by crusts formed of skeletal organisms (bryozoans, nubecularians), while the middle parts of fissures are composed of organodetrital material, often bivalve and gastropod shells (Figs. 3-5). Similar Sarmatian material fills caverns in the Badenian reefs, often several metres below their tops (e.g., in Polupanivka). Some fissures include breccias or conglomerates containing clasts of various Sarmatian rocks (serpulid-microbialite limestones, crusts of encrusting organisms) and in some cases also Badenian reef limestones.

The walls of fissures are usually coated with 1 to 3 generations of microbial encrustations (Figs. 6-9), that are virtually identical to microbialites forming the overlying Sarmatian reefs (see Jasionowski, 2006). Several generations of wall coatings occur, and each generation shows a distinct growth pattern, which in wider fissures is clearly phototropic. Microbial encrustations show various fabrics; they are mostly clotted and massive, and in some cases peloidal clotted fabrics are made up of aggregates of small peloids and sparitic rims. In places, in particular in narrow fissures, encrusting coralline algae, foraminifers and bryozoans are included in the coatings. In the central part of fissures, bedded deposits containing Sarmatian bivalves (mostly the cockle Obsoleliforma and mytilids) and various gastropods (e.g., Mohrensternia, Calliostoma, Cerithium) occur.

\section{GEOCHEMISTRY}

Mineralogy (XRD) and geochemistry (XRF) of fissure microbialites and cements are shown in Table 1, and Figure 10 shows magnesium and strontium contents in various components of Sarmatian reefs of Medobory and fissure microbialite coatings in the Maksymivka Quarry. They usually contain negligible terrigenous admixture as shown by low contents of $\mathrm{SiO}_{2}$ and $\mathrm{Al}_{2} \mathrm{O}_{3}$.

The $\delta^{18} \mathrm{O}$ and $\delta^{13} \mathrm{C}$ values measured in the microbial coatings are quite variable (Table 2 and Fig. 11). The $\delta^{18} \mathrm{O}$ values range (except for one isotopically extremely light sample M2-5 - that was excluded) is from -5 to $+0.5 \%$ (VPDB) (mean is $-1.3 \%$; standard deviation $-1.6 \%$ ). They are in average shifted ca. $1.7 \%$ o towards lower values in comparison to the microbialites constructing Sarmatian reefs (their mean is about $0 \%$, ranging from ca. -3 to ca. $+2.5 \%$ o [VPDB] - see Jasionowski, 2006). The $\delta^{13} \mathrm{C}$ values range from -2 to over $+2.5 \%$ [VPDB] (mean $+1.25 \%$; standard deviation $1.2 \%$ ) and are merely slightly lower than those typical of the Sarmatian reef microbialites (mean 1.9\%o, ranging from 0 to $+2.8 \%$ o [VPDB] - see Jasionowski, 2006). No apparent isotopic trends across the microbialite growth profiles are observed both for $\delta^{18} \mathrm{O}$ and $\delta^{13} \mathrm{C}$.

\section{FORAMINIFERS}

At Maksymivka, the following taxa were identified in sample III of a weakly cemented coquina: Lobatula lobatula (Walker et Jacob), Elphidium aculeatum (d'Orbigny), Elphidium macellum (Fichtell et Moll), Elphidium sp., Articulina problema Bogdanowicz, Pseudotriloculina consobrina (d'Orbigny), Quinqueloculina sarmatica Karrer (Fig. 12); Lobatula lobatula dominates the assemblage (Fig. 13). The following taxa occur in sample II: Quinqueloculina sarmatica Karrer, $Q$. akneriana d'Orbigny, Varidentella podolica (Didkowski), V. inflatecarinata (Venglinski), Pyrgo clypeata (d'Orbigny). Triloculina sp., Lobatula lobatula (Walker et Jacob), Elphidium joukovi (Serova) (Figs. 12 and 13). This assemblage is dominated by small hauerinids (Fig. 13).

At Hai Roztotski, sample 5 contains a Lobatula lobatula assemblage with dominant Lobatula lobatula (Walker et Jacob) (90\%), rare Cycloforina spp. and Varidentella spp., and sporadic Porosononion martkobi (Bogdanowicz), Elphidium excavatum (Terquem), Nonion tumidulus Pishvanova, Articulina problema Bogdanowicz and Quinqueloculina sarmatica Karrer (Figs. 13 and 14). Sample 7 is characterized by an Elphidium hauerinum assemblage, Elphidium hauerinum (d'Orbigny) is accompanied by E. excavatum (Terquem), E. macellum converia Venglinski, E. macellum tumidocamerale Bogdanowicz and Porosononion martkobi (Bogdanowicz); there are very rare hauerinids - Cycloforina spp., Varidentella rotunda (Gerke) and Triloculina inflata d'Orbigny (Figs. 13 and 14). Sample 8 yielded Elphidium hauerinum assemblage with very rare hauerinids (Fig. 13).

In samples from Polupanivka the assemblage is dominated by elphidiids and hauerinids (Fig. 13; Peryt and Jasionowski, 2012).

\section{INTERPRETATION}

The fissures recorded are regarded as neptunian dykes. We apply the definition given by Playford (1984) for the sedimentary filling of a fissure that cut the bedding of the host rock and formed relatively soon after deposition in early-cemented limestones. Neptunian dykes may form due to (1) tectonic mechanisms that cause rock fracturing or initiate gravitational movement or (2) high local depositional relief and sediment instabil- 

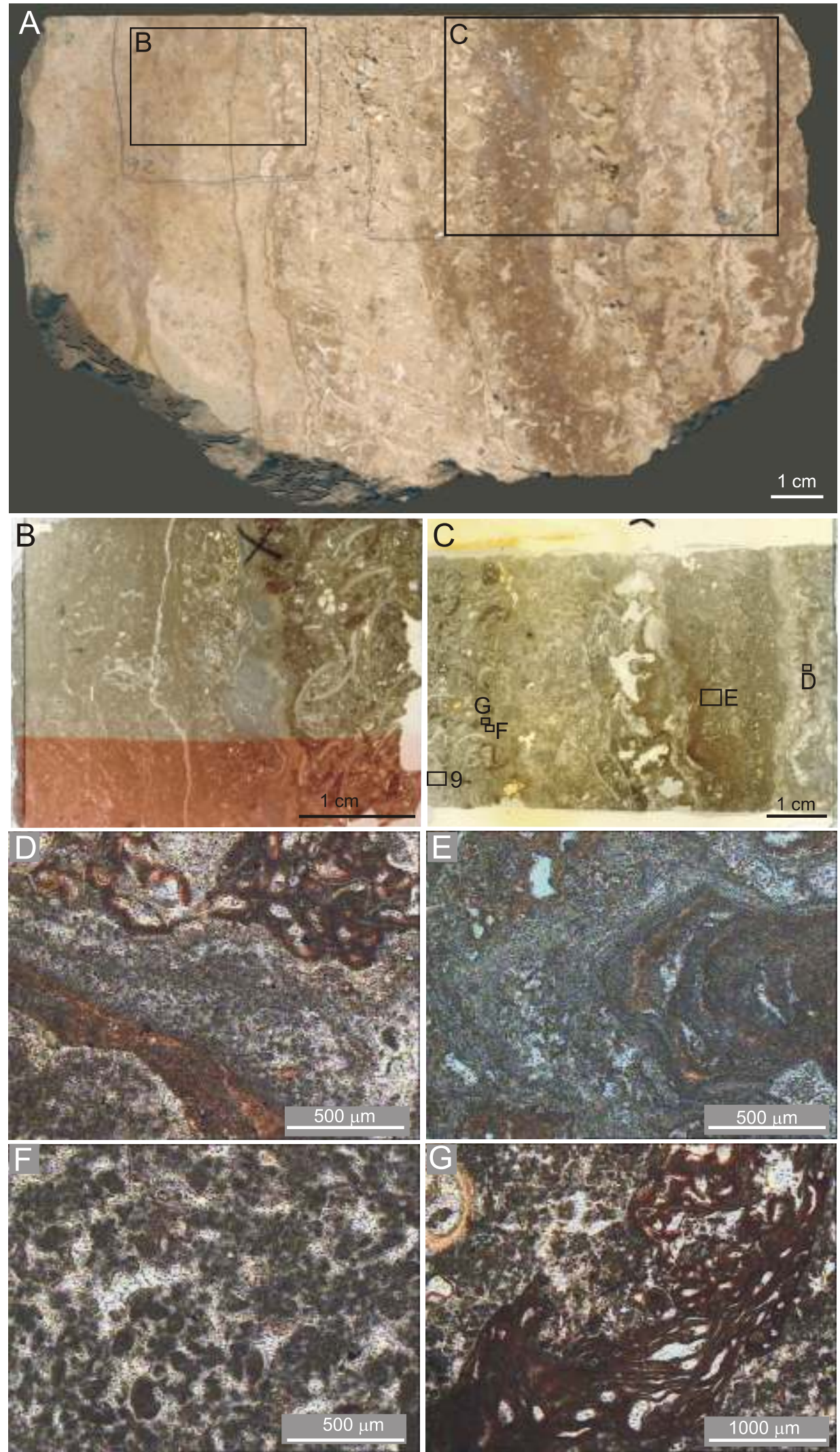

Fig. 8. Narrow fissure infilling with microbialite, coralline algal and nubecularid foraminifer encrustations at the edges and bioclastic deposits in the centre (Maksymivka, sample M2-2)

$\mathbf{A}$ - polished slab across the whole fissure fill in natural position; $\mathbf{B}, \mathbf{C}$ - microphotographs of thin sections (see A for location); D-G - details of the fissure infilling (boxes at C mark positions of each microphotograph): D nubecularid foraminifer (top) coated with microbialite, E - columnar structure built by tiny coralline algal coatings, $\mathrm{F}$ - microbialite with clotted fabrics, $\mathrm{G}$ - coralline algal encrustation embedded in microbialite 


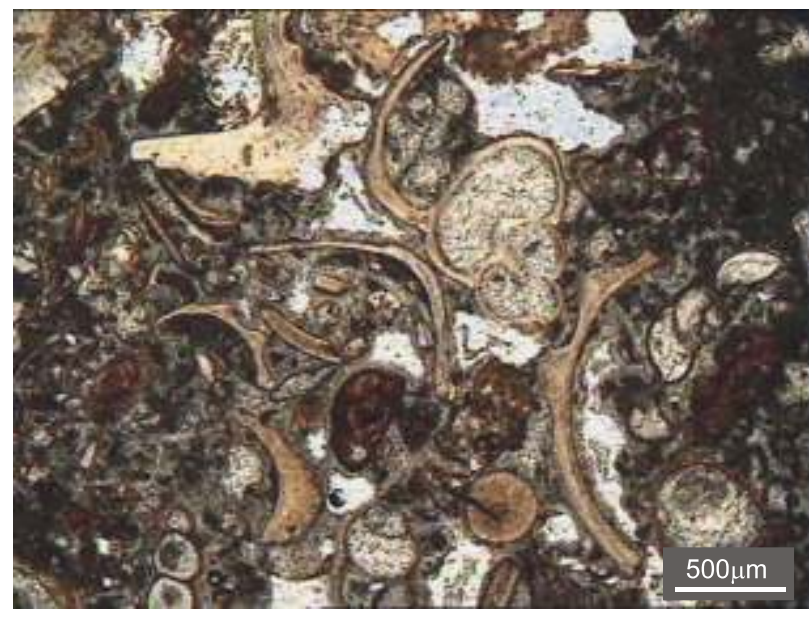

Fig. 9. Bioclastic infilling in the center of the fissure (Maksymivka Quarry)

For location see Figure 8C

ity that results in passive gravitational movement and fracturing of the rock (Stanton and Pray, 2004). By either mechanism, the host rock must be lithified in order to fracture and form a sfisure. Most neptunian dykes occur where steep depositional slopes and early lithification favoured gravitational fracturing including slumping along an oversteepened depositional margin or bending and fracturing of lithified strata as a result of compaction of underlying unconsolidated sediment (Stanton and Pray, 2004). In the case of Medobory, the orthogonal network of dykes and parallel joints strongly suggest that they are tectonically-controlled.

The fissure fillings containing both the Sarmatian material as well as rare clasts of the Badenian rocks indicate that the fissure were open during Sarmatian deposition. The Sarmatian material includes both characteristic microbialites as well as Elphidium reginum (d'Orbigny) and E. josephinum (d'Orbigny) that are regarded to be diagnostic for the Early Sarmatian, although the first species occurs also in the Upper Badenian strata in Roztocze (Szczechura, 1982) and at Kudryntsi, some $25 \mathrm{~km}$ west of the Medobory Ridge (Peryt and Peryt, 2009).

These fillings originated following the fracturing of the Badenian limestones due to fault tectonics at basin margins induced by basin subsidence, around the Badenian-Sarmatian boundary, and/or through gravitational instability of large lithified Badenian reef bodies. We assume that there occurred only one phase of fracture opening. The joint sets could serve as conduits of the freshwater, which led to karstification during the sea level withdrawal from the area. Subsequently, fractures

$\mathrm{Sr}$
$[\mathrm{ppm}]$ were modified by submarine abrasion possibly related to the transgression-related planation surface recorded at Maksymivka (Radwański et al., 2006b). The filling of fractures occurred, as in typical neptunial dykes (Playford, 1984), by combination of sediments pouring in from above, organic growth (mostly microbial and encrusting foraminiferal) and cementation. There is no evidence of filling episodes due to tectonic instability by successive collapses of the fracture walls, as commonly observed in neptunian dykes (e.g., Vennin, 2007); instead, microbial crusts on the fracture walls and then lithoclasts of Badenian and Sarmatian rocks as well as bioclastic sediments suggest a passive sediment-fill by gravitational-induced processes.

The fracturing resulted in sharp sidewalls of the fissures. Fractures were cryptic habitats. In recent reef niches where marine microbialites are common structures in cavities and fractures (Reitner et al., 2000), they contribute to fracture filling as fixing and binding organisms.

The first generations of fracture infilling consist of microbial encrustations. Their geochemical characteristics (first of all relatively high contents of $\mathrm{Mg}$ and $\mathrm{Sr}$ ) as well no obvious petro-
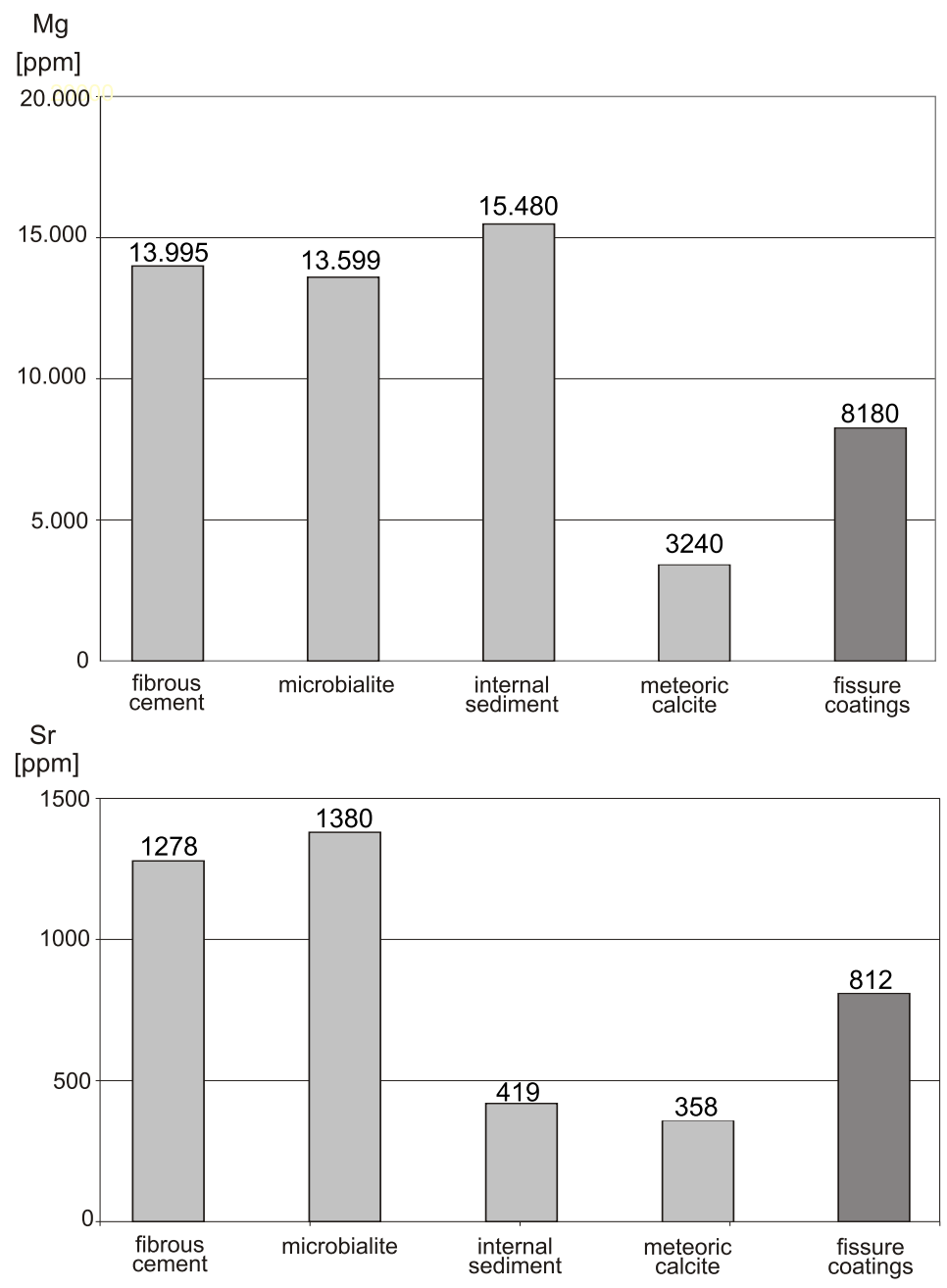

Fig. 10. Magnesium and strontium contents in various components of Sarmatian serpulid-microbialite reefs of Medobory and fissure microbialite coatings in the Maksymivka Quarry 


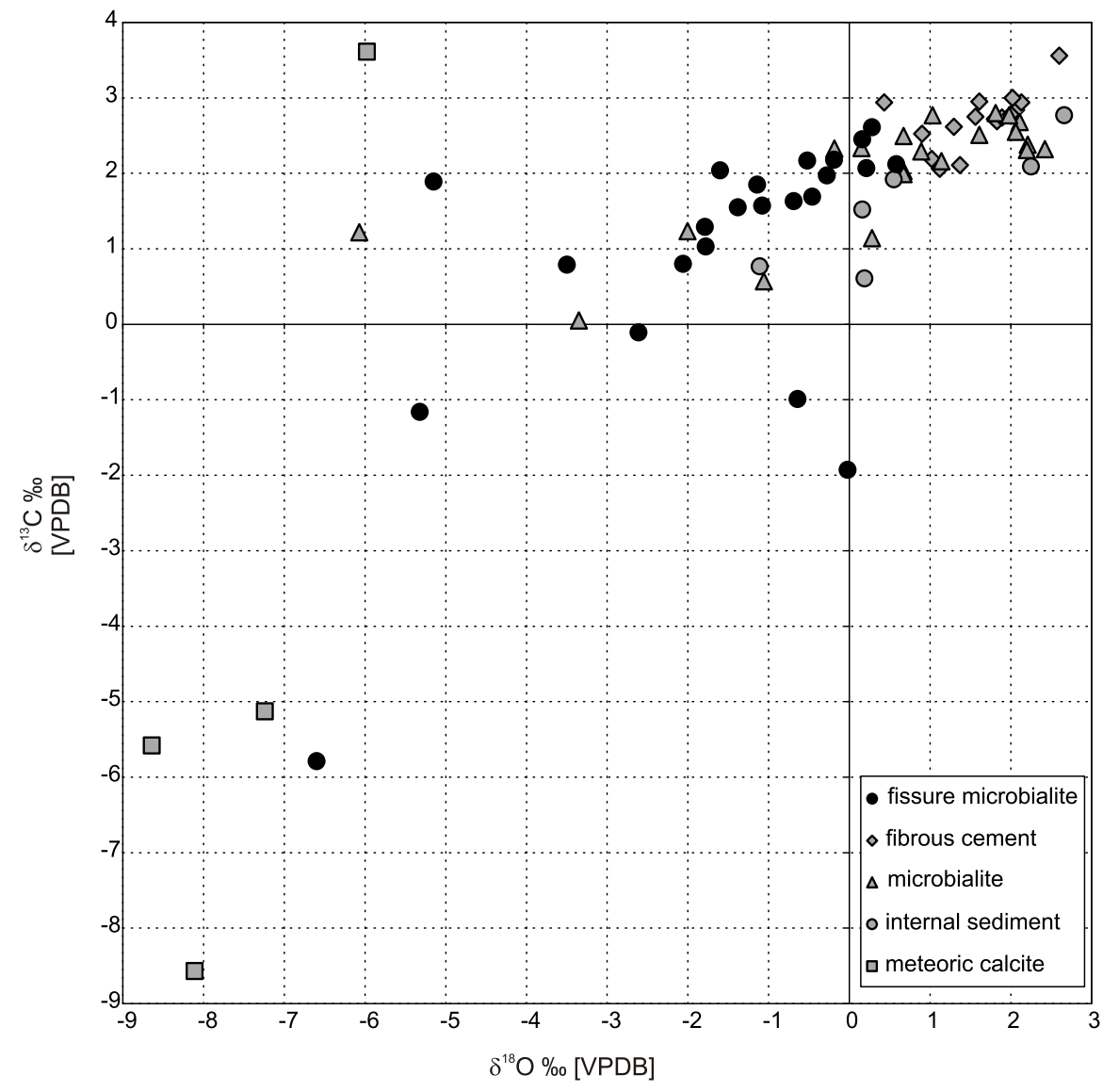

Fig. 11. Oxygen and carbon stable isotopes values of various components of the serpulid-microbialite reefs (from Jasionowski, 2006) and the fissure microbialites (this study)

graphic signatures of meteoric diagenesis (such as dissolution or recrystallisation) seem to indicate that they remained diagenetically unaltered. The complex nature of microbialites as well as their geochemical record indicate fluctuating environmental conditions during the initial phases of infilling. The second phase of infilling typically consists of bioclastic limestone; the composition of bioclasts is identical to that recorded in the adjacent Sarmatian reef area (cf. Radwański et al., 2006a, b). The bioclasts are greater in dimension and abundance compared to those of the microbialites. In general, sediments filling the neptunian dykes correspond to sediments deposited in the adjacent reef area, and thus, the sedimentary environment in narrow channels did not differ significantly from that on the sea-floor.

The conclusion is supported by geochemical data that indicate that the $\mathrm{Mg}$ and $\mathrm{Sr}$ concentrations in microbial precipitates in the fissures are similar to those characteristic of microbialites of the Sarmatian reefs (see Jasionowski, 2006, for details). However, the $\delta^{18} \mathrm{O}$ values measured in the microbial coatings are lower by about $1.5 \%$ o than those characteristic of the reef microbialites and thus they may indicate less saline water during microbialitic precipitation in the fissures than during the deposition of the Sarmatian serpulid-microbialite reefs. The last originated in semi-marine, brackish but strongly evaporated water; the evaporation explains their relatively heavy oxygen isotope signatures (see Jasionowski, 2006; Studencka and
Jasionowski, 2011). In turn, the $\delta^{13} \mathrm{C}$ values in the fissure microbialites are almost identical to values encountered in the Sarmatian reefs with no indication of a considerable contribution of organic carbon dioxide.

Each of the samples from fissure infillings studied for foraminifers can be easily ascribed to one of four foraminiferal assemblages that differ by the proportions of the species and groups of benthic foraminifers occurring: Lobatula lobatula (Maksymivka III, Hai Roztotski 5, Polupanivka 5), hauerinid (Maksymivka II, Polupanivka 4), Elphidium aculeatum (Polupanivka 3) and Elphidium hauerinum (Hai Roztotski 7, 8) (Fig. 13). In Maksymivka, so far two foraminiferal assemblages have been recognized: a hauerinid assemblage and a Lobatula lobatula assemblage, and in both Hai Roztotski and Polupanivka three assemblages occur (Fig. 13).

Foraminiferal assemblages from Hai Roztotski are dominated by forms of Elphidium which have a rounded test margin and do not possess a keel. Such forms are characterized by very low environmental requirements (Murray, 1991, 2006): they can exist in shallow environments of water salinity ranging from 0 to $70 \%$, and occur in brackish to hypersaline marshes and lagoons as well as in internal shelf conditions. Nonion has similar environmental needs, whereas hauerinids (Quinqueloculina, Cycloforina, Varidentella, Triloculina, Pyrgo) prefer 


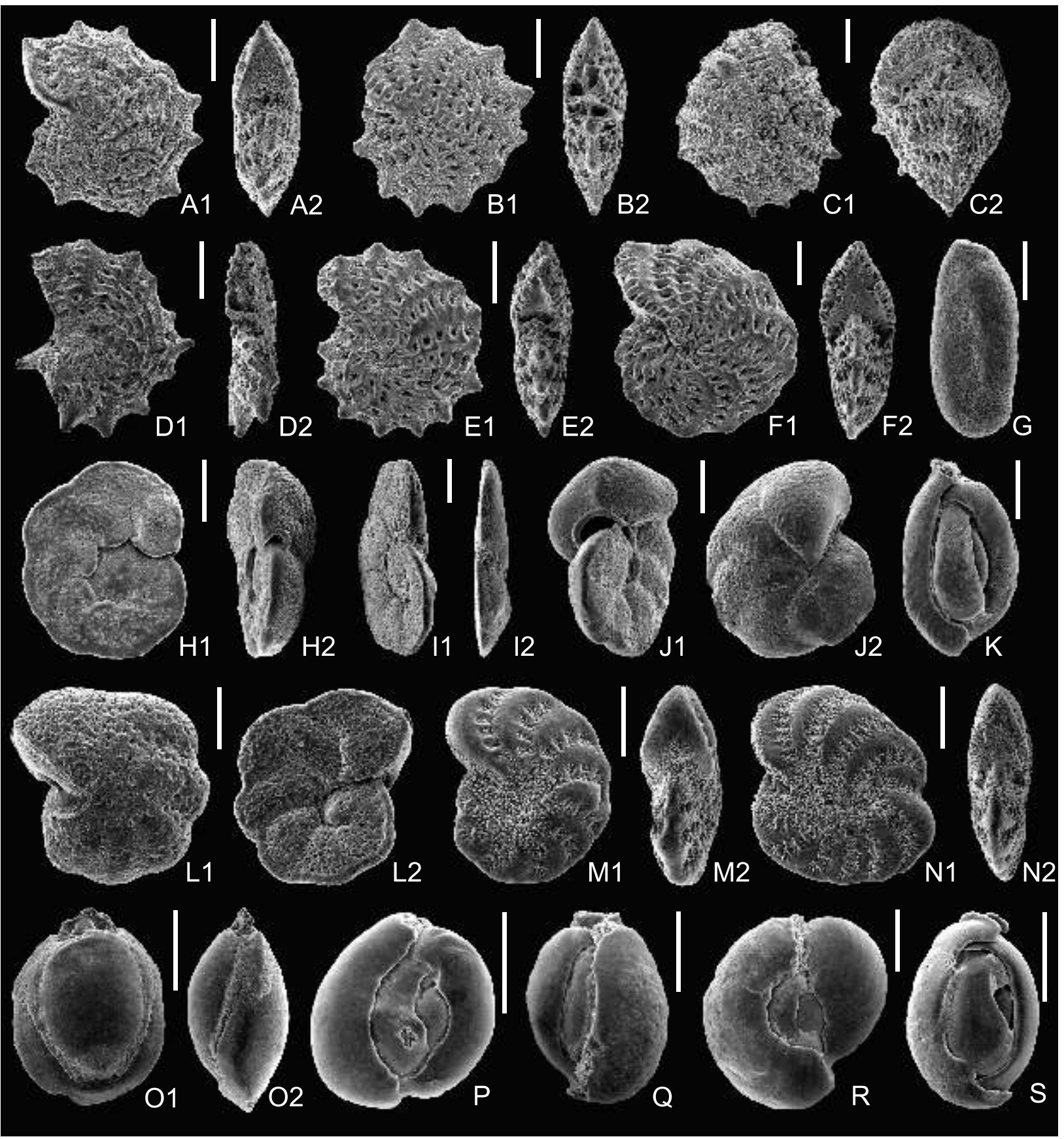

Fig. 12. Foraminifers from the Maksymivka fissure infillings

A, B, D, E - Elphidium aculeatum (d'Orbigny); C - Elphidium sp.; F - Elphidium macellum (Fichtell et Moll); G - Pseudotriloculina consobrina (d'Orbigny); H-J, L - Lobatula lobatula (Walker et Jacob); K - Quinqueloculina sarmatica Karrer (mould); M, N - Elphidium joukovi (Serova); O - Pyrgo clypeata (d'Orbigny) (mould); P - Varidentella podolica (Didkowski) (mould); Q - Triloculina sp. (mould); R Varidentella inflatecarinata (Venglinski) (mould); S - Quinqueloculina akneriana d'Orbigny (mould); A-J - sample III; K-S - sample II; 1 lateral view, 2 - edge view; scale bars $200 \mu \mathrm{m}$

shallow marine environments (0-50 m deep) of normal salinity to hypersaline characteristic of lagoons.

Three foraminiferal assemblages were recorded in Polupanivka: an Elphidium aculeatum assemblage characterized by low diversity and high dominance with common aberrant forms, indicating a calm shallow-water marine environment with elevated salinity, a Hauerinidae assemblage suggesting shallow marine environments ( $0-50 \mathrm{~m}$ deep) of normal salinity to hypersaline characteristic of lagoons, and a Lobatula lobatula assemblage suggesting a shallow-marine, very high-energy environment (Peryt and Jasionowski, 2012). Monospecific or very low taxonomic diversity foraminiferal assemblages indicate a stressed environment, characterized by physicochemical parameters considerably different from those characteristic of typical marine 


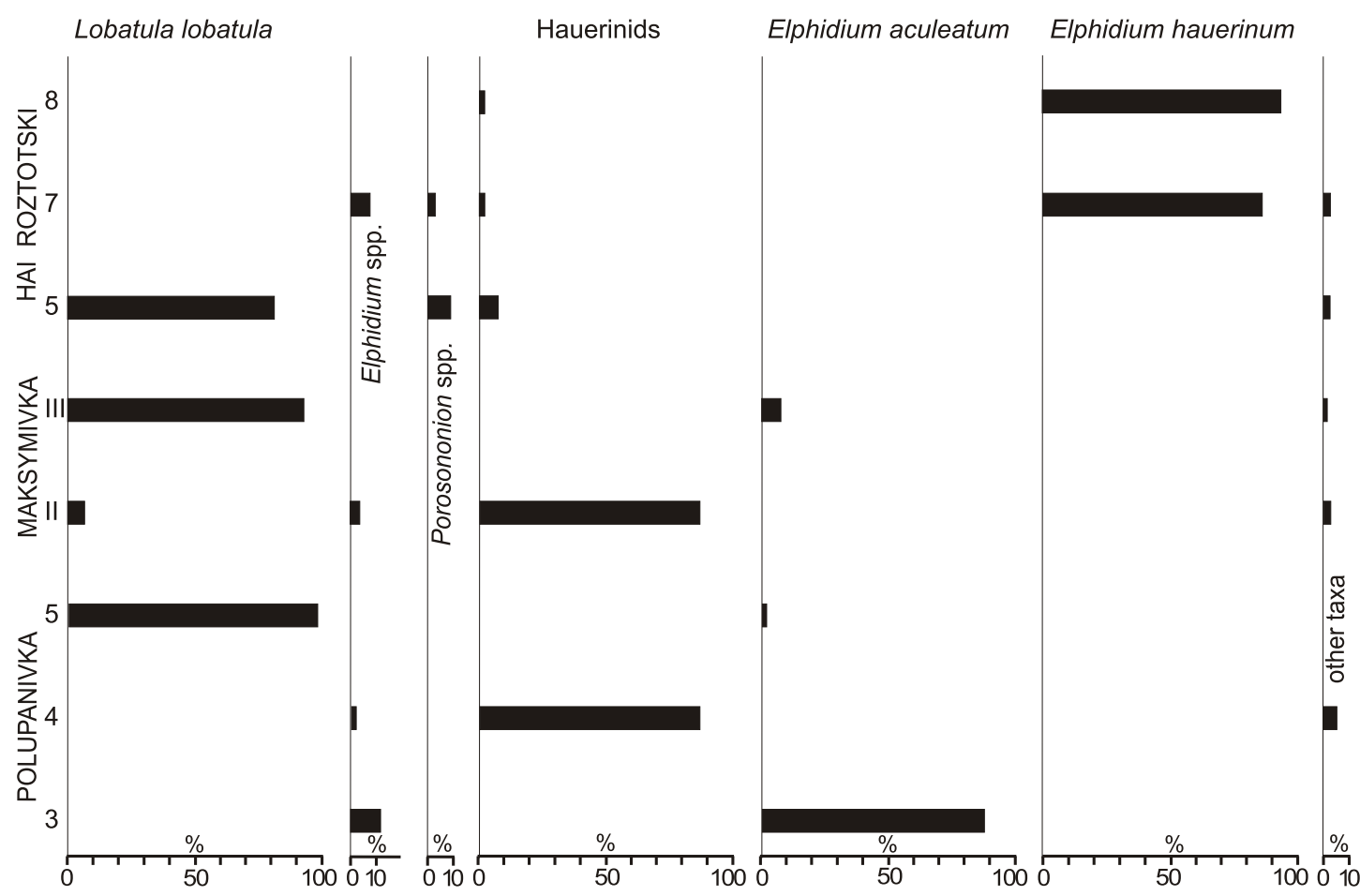

Fig. 13. Relative abundances of benthic foraminiferal species and groups in the fissure infillings (numbers indicate samples discussed in the text)

environments (e.g., Peryt et al., 2004). The predominance of the keeled elphidiids suggests a dense arborescent algal substrate during the Early Sarmatian (Langer, 1993; Tóth and Görög, 2008). Lobatula lobatula is a permanently attached foraminifer that often lives on seagrass leaves or rhizomes (Langer, 1993), and thus the change of an Elphidium assemblage to a Lobatula lobatula assemblage in all studied sites is explained by the transition of algal into seagrass vegetation (cf. Tóth and Görög, 2008) in the source area.

\section{DISCUSSION}

A considerable hiatus at the Badenian/Sarmatian boundary is indicated by a strongly erosive discordance recorded in many places within the Pannonian Basin System (Kojumdgieva, 1969; Harzhauser and Piller, 2004, 2007; Piller and Harzhauser, 2005; Kováč et al., 2007; Rögl et al., 2008) as well as on the northern margin of the Euxine-Caspian Basin System (Nevesskaja et al., 1987). It seems that the abrasion surface inferred for the Maksimivka site is related to that boundary.

There is remarkable similarity between the initial fissure fillings and the oldest Sarmatian deposits on the top of the Badenian reef that are locally formed by several-cm-thick bed of fine columnar stromatolites (cf. Fig. 6A) and by breccias and conglomerates composed of the Badenian and Sarmatian reefs in other places (Radwański et al., 2006b). The presence of characteristic clasts of Sarmatian microbialites indicates that the fissures were open at the onset of Sarmatian deposition in the Medobory area, however, they were sealed not long after marine deposition was restored in the area.

The general sharp sidewalls of the fissures indicate that the time interval between the fracturing and the onset of Sarmatian deposition was short. On the other hand, the process of fracture filling was quite long-lasting as indicated by the presence of various foraminiferal assemblages. The lowermost Sarmatian beds are often characterized by low diversity faunal assemblages and the almost complete absence of stenohaline forms prior to a transgressive event (Tóth et al., 2010 with references therein). The variable composition of foraminifer assemblages implies very unstable marginal marine conditions (Koubová and Hudáčková, 2010).

\section{CONCLUSIONS}

1. The fissure network recognised within the topmost part of Upper Badenian reef limestones of the Medobory Hills (western Ukraine) represents a system of neptunian dykes, where steep depositional slope and lithification of Badenian reefs favoured fracturing associated with tectonics.

2. The dykes are filled with several generations of Sarmatian microbial deposits coating the fracture walls and with bedded bioclastic sediment (including foraminifers) which is more important volumetrically; this loose material accumulated on the sea bottom and fell into the extensional fractures. 


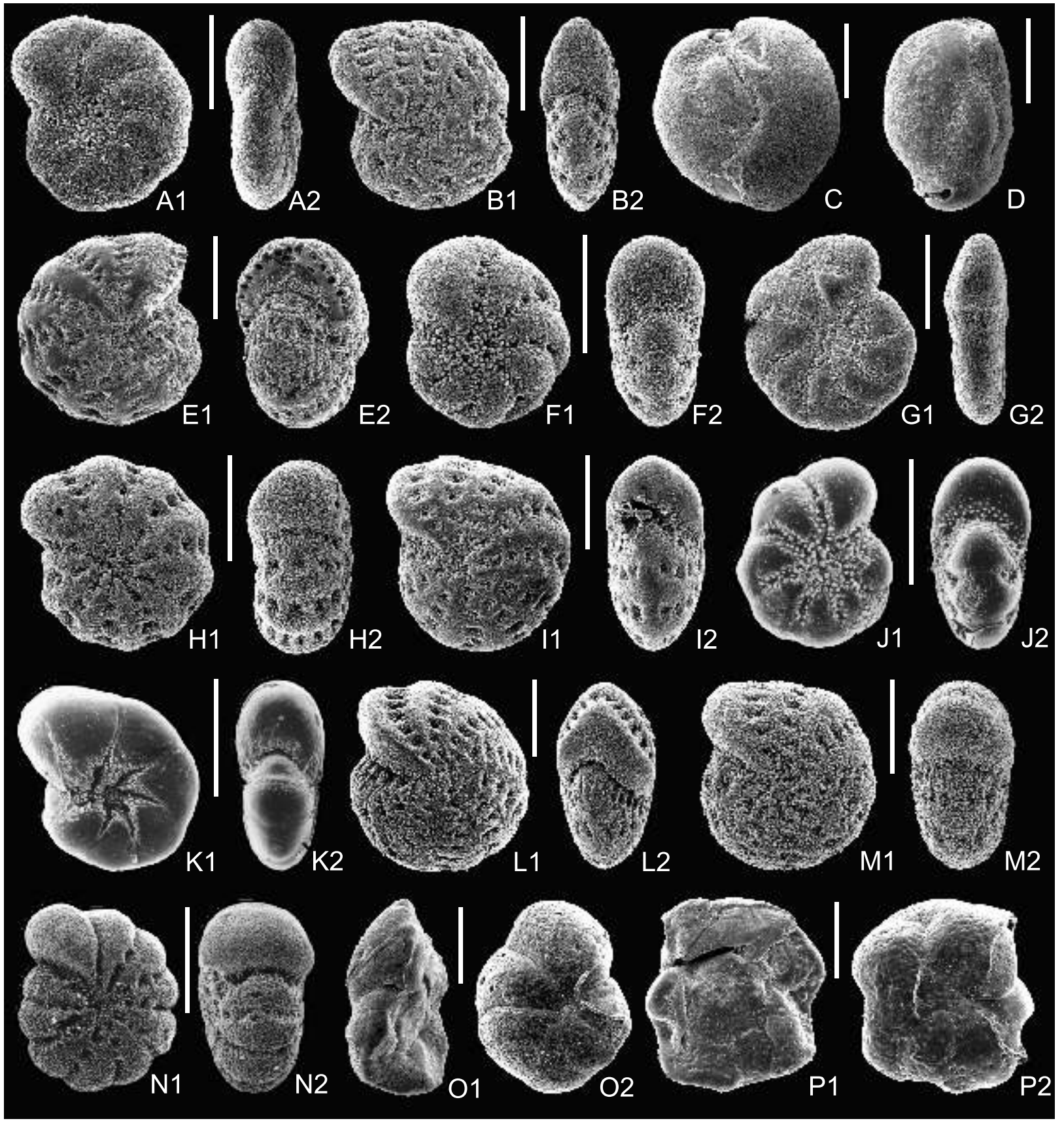

Fig. 14. Foraminifers from the Hai Roztotski fissure infillings

A, G - Porosononion martkobi (Bogdanowicz); B - Elphidium macellum tumidocamerale Bogdanowicz; C - Varidentella rotunda (Gerke); D Triloculina inflata d'Orbigny; E, H, I, M - Elphidium hauerinum (d'Orbigny); F, J - Elphidium excavatum (Terquem); K - Nonion tumidulus Pishvanova; L - Elphidium macellum converia Venglinski; N-Elphidium sp.; O, P-Lobatula lobatula (Walker et Jacob); A-I, L - sample 7; J, K, N-P - Sample 5; M - sample 8; 1 - lateral view, 2 - edge view; scale bars $200 \mu \mathrm{m}$

3. Four foraminiferal assemblages (Lobatula lobatula, hauerinid, Elphidium aculeatum, and Elphidium hauerinum) were recorded in the neptunian dykes which indicates that the process of fracture filling was relatively long-lasting and continual marine conditions were established.
Acknowledgements. This study was supported by the projects 3 P04D 06420 (Polish Committee for Scientific Research) and N 307113635 (Polish Ministry of Science and Higher Education). We thank A.V. Poberezhskyy for field assistance, and Th. Brachert, F. Pomoni-Papaioannou and J. Sotak for helpful comments and remarks on the first draft of the paper. 


\section{REFERENCES}

AL-AASM I.S., TAYLOR B.E. and SOUTH B. (1990) - Stable isotope analysis of multiple carbonate samples using selective acid extraction. Chem. Geol., 80: 119-125.

ANDREYEVA-GRIGOROVICH A.S., KULCHYTSKY Y.O., GRUZMAN A.D., LOZYNYAK P.Y., PETRASHKEVICH M.I., PORTNYAGINA L.O., IVANINA A.V., SMIRNOV S.E., TROFIMOVICH N.A., SAVITSKAYA N.A. and SHVAREVA N.J. (1997) - Regional stratigraphic scheme of Neogene formations of the Central Paratethys in the Ukraine. Geol. Carpath., 48 (2): 123-136.

GEDL P. and PERYT D. (2011) - Dinoflagellate cyst, palynofacies and foraminiferal records of environmental changes related to the Late Badenian (Middle Miocene) transgression at Kudryntsi (western Ukraine). Ann. Soc. Geol. Pol., 81 (3): 331-339.

GESLIN E., STOUFF V., DEBENEY J-P. and LESOURD M. (2000) - Environmental variation and foraminiferal test abnormalities. In: Environmental Micropaleontology (ed. R.E. Martin): 192-215. Kluwer Academic/Plenum Publishers, New York.

GÓRKA M., GÓRKA M., STUDENCKA B., JASIONOWSKI M., HARA U., WYSOCKA A. and POBEREZHSKYY A. (2012) - The Medobory Hills (Ukraine). Middle Miocene reef systems in the Paratethys: Their biological diversity and litofacies. Biul. Państw. Inst. Geol., 449 147-174.

HARZHAUSER M. and PILLER W.E. (2004) - The Early Sarmatian - hid den seesaw changes. Cour. Forsch.-Inst. Senckenberg, 246: 89-111.

HARZHAUSER M. and PILLER W.E. (2007) - Benchmark data of a changing sea - palaeogeography. palaeobiogeography and events in the central Paratethys during the Miocene. Palaeogeogr. Palaeoclimatol. Palaeoecol., 253: 8-31.

HAYWARD B.W., HOLLIS C.J. and GRENFELL H.R. (1997) - Recent Elphidiidae (Foraminiferida) of the South-west Pacific and fossil Elphidiidae of New Zealand. Inst. Geol. Nuclear Sc. Monographs, 16: $1-170$.

JANAKEVICH A.N. (1977) - Middle Miocene reefs of Moldavia (in Russian). Shtiintsa Publishers, Kishinev: 1-116.

JASIONOWSKI M. (2006) - Facies and geochemistry of Lower Sarmatian reefs along the northern margin of the Paratethys in Roztocze (Poland) and Medobory (Ukraine) regions: paleoenvironmental implications (in Polish with English summary). Prz. Geol., 54 (5): 445-454.

KLIMCHOUK A.B., ANDREJCHOUK V.N. and TURCHINOV I.I (1995) - Structural prerequisites of speleogenesis in gypsum in the western Ukraine. Ukrainian Speleological Association.

KOJUMDGIEVA W. (1969) - Les fossilles de Bulgarie. VIII Sarmatien (in Bulgarian with French summary). Académie des Sciences de Bulgarie; Sofia.

KOROLYUK I.K. (1952) - Podolian toutres and conditions of their origin (in Russian). Trans. Geol. Inst., Acad. Sc. USSR, 59: 1-136.

KOUBOVÁ I. and HUDÁČKOVÁ V. (2010) - Foraminiferal successions in the shallow water Sarmatian sediments from the MZ 93 borehole (Vienna Basin, Slovak part). Acta Geol. Slov., 2 (1): 47-58.

KOVÁČ M., ANDREYEVA-GRIGOROVICH A., BAJRAKTAREVIC Z., BRZOBOHATÝ R., FILIPESCU S., FODOR L., HARZHAUSER M., NAGYMAROSY A., OSZCZYPKO N., PAVELIČ D., RÖGL F., SAFTIČ B., SLIVA L. and STUDENCKA B. (2007) - Badenian evolution of the Central Paratethys Sea: paleogeography. climate and eustatic sea-level changes. Geol. Carpath., 58: 579-606.

LANGER M.R. (1993) - Epiphytic foraminifera. Mar. Micropaleont., 20: 235-265.

MASLOV V.P. (1962) - Fossil red algae of USSR and their relationships with the facies (in Russian). Trans. Geol. Inst., Acad. Sc. USSR, 53: $1-222$.

MASLOV V.P. and UTROBIN V.N. (1958) - Distribution of the Tertiary Rhodophyceae of the Ukrainian Soviet Socialist Republic and their connection with sea transgression (in Russian). Bull. Acad. Sc. USSR. ser. geol., (12): 73-93.

MURRAY J.W. (1991) - Ecology and palaeoecology of benthic foraminifera. Longman Scientific and Technical, Avon.

MURRAY J.W. (2006) - Ecology and applications of benthic foraminifera. Cambridge University Press, Cambridge.
NEVESSKAJA L.A., GONCHAROVA I.A., ILJINA L.B., PARAMONOVA N.P., POPOV S.V., VORONINAA.A., CHEPALYGA A.L. and BABAK E.V. (1987) - History of Paratethys. Ann. Inst. Geol. Publ. Hung., 70: 337-342.

OSZCZYPKO N., KRZYWIEC P., POPADYUK I. and PERYT T. (2006) Carpathian Foredeep Basin (Poland and Ukraine) - its sedimentary. structural and geodynamic evolution. AAPG Mem., 84: 293-350.

PERYT D. and JASIONOWSKI M. (2012) - Sarmatian foraminifer assemblages of cavern fillings in the Badenian reefs of Medobory (Polupanivka, western Ukraine). Biul. Państw. Inst. Geol., 449: 175-184.

PERYT D. and PERYT T.M. (2009) - Environmental changes in the declining Middle Miocene Badenian evaporite basin of the Ukrainian Carpathian Foredeep (Kudryntsi section). Geol. Carpath., 60: 505-517.

PERYT T.M., PERYT D., JASIONOWSKI M., POBEREZHSKYY A.V. and DURAKIEWICZ T. (2004) - Post-evaporitic restricted deposition in the Middle Miocene Chokrakian-Karaganian of East Crimea (Ukraine). Sedim. Geol., 170: 21-36.

PILLER W.E. and HARZHAUSER M. (2005) - The myth of the brackish Sarmatian Sea. Terra Nova, 17: 450-455.

PLAYFORD P.E. (1984) - Platform-margin and marginal-slope relationships in Devonian reef complexes of the Canning Basin. In: The Canning Basin, W.A (ed. P.G. Purcell): 189-214. Proceedings of Geol. Soc. Aust./Pet. Expl. Soc. Aust. Symposium, Perth.

RADWAŃSKI A., GÓRKA M. and WYSOCKA A. (2006a) - Middle Miocene coralgal facies at Maksimivka near Ternopil (Ukraine): a preliminary account. Acta Geol. Pol., 56: 89-103.

RADWAŃSKI A., GÓRKA M., JASIONOWSKI M., STUDENCKA B., WYSOCKA A. and HARA U. (2006b) - Stop III - Maksymówka (Maksymivka). In: Przebieg i zmienność sedymentacji w basenach przedgórskich (eds. A. Wysocka and M. Jasionowski): 75-79. Materiały Konferencyjne II Polskiej Konferencji Sedymentologicznej, Zwierzyniec, 20-23.06.2006.

REITNER J., THIEL V., ZANKL H., MICHAELIS W., WORHEIDE G. and GAUTRET P. (2000) - Organic and biogeochemical patterns in cryptic microbialites. In: Microbial Sediments (eds. R. Riding and S.M. Awramik): 149-159. Spinger, Berlin.

RÖGL F., ĆORIĆ S., HARZHAUSER M., JIMENEZ-MORENO G., KROH A., SCHULTZ O., WESSELEY G. and ZORN I. (2008) - The Middle Miocene Badenian stratotype at Baden-Sooss (Lower Austria). Geol. Carpath., 59 (5): 367-374.

SMART P.L., PALMER R.J., WHITAKER F. and WRIGHT V.P. (1988) Neptunian dikes and fissure fills: an overview and account of some modern examples. In: Paleokarst (eds. N.P. James and P.W. Choquette): 149-163. Springer. Berlin.

STANTON R.J. and PRAY L.C. (2004) - Skeletal-carbonate neptunian dikes of the Capitan Reef: Permian, Guadalupe Mountains, Texas, U.S.A. J. Sedim. Res., 74 (6): 805-816.

STUDENCKA B. and JASIONOWSKI M. (2011) - Bivalves from the Middle Miocene reefs of Poland and Ukraine: a new approach to Badenian/Sarmatian boundary in the Paratethys. Acta Geol. Pol., 51: 79-114.

SZCZECHURA J. (1982) - Middle Miocene foraminiferal biochronology and ecology of SE Poland. Acta Palaeont. Pol., 27: 1-44.

TÓTH E. and GÖRÖG G. (2008) - Sarmatian foraminifera fauna from Budapest (Hungary). Hantkeniana, 6: 187-217.

TÓTH E., GÖRÖG A., LÉCUYER C., MOISSETTE P., BALTER B. and MONOSTORI M. (2010) - Palaeoenvironmental reconstruction of the Sarmatian (Middle Miocene) central Paratethys based on palaeontological and geochemical analyses of foraminifera, ostracods, gastropods and rodents. Geol. Mag., 147 (2): 299-314.

VENNIN E. (2007) - Coelobiontic communities in neptunian fissures of synsedimentary tectonic origin in Permian reef, southern Urals, Russia. Geol. Soc. Spec. Publ., 275: 211-227.

WYSOCKA A., RADWAŃSKI A. and GÓRKA M. (2012) - Mykolaiv Sands in the Opole Minor and beyond: sedimentary features and biotic content of Middle Miocene (Badenian) sand shoals of western Ukraine. Geol. Quart., 56 (3): 475-492. 